AGATA MIĘTEK

Wydział Prawa i Administracji UMK

\title{
Miejsce Johna Mitchella Finnisa we współczesnej teorii prawa
}

Clem niniejszej noty nie jest całościowe przedstawienie teorii prawa naturalnego, którą zbudował John Finnis. Co więcej, nie jest nim nawet przybliżenie zarysu tej teorii, gdyż i to zajęłoby daleko więcej miejsca niż tych kilka zdań. Poniższe rozważania mają na celu jedynie przybliżenie postaci Johna Finnisa, cieszącego się znacznym uznaniem za granicą, któremu jednak w Polsce nie poświęcono zbyt wiele uwagi. A przecież trudno byłoby uznać za pełne i zadowalające jakiekolwiek rozważanie o współczesnej jurysprudencji pomijające tego właśnie filozofa. Poniższy wywód jest więc rodzajem przynęty, która może zmusić do dalszych poszukiwań.

John Mitchell Finnis urodził się w 1940 roku w Australii. W 1961 roku ukończył studia na australijskim University of Adelaide (St. Mark's College), jednak już doktorat przygotowywał w Europie na uniwersytecie w Oxfordzie, gdzie był uczniem H. L. A. Harta. Godny uwagi jest fakt, iż Hart wykształcił całą rzeszę niezwykle ważnych teoretyków i filozofów prawa, by wymienić wśród nich tylko Ronalda Dworkina, Josepha Raza, Neila MacCormicka czy Briana Barrego. Obecnie Finnis dzieli swoją pracę pomiędzy tym uniwersytetem a amerykańską uczelnią Notre Dame. Ta ostatnia liczy sobie ponad 150 lat i jest określana jako niezależny, katolicki uniwersytet ${ }^{1}$, znany powszechnie jako ośrodek, w którym rozważane są kwestie prawa naturalnego. Prócz tego Finnis wykładał w wielu innych miejscach, na kilku kontynentach, by wymienić tylko: University of California w Berkeley (1965-66), afrykański

\footnotetext{
${ }^{1}$ About Notre Dame, dostępne: http://nd.edu/aboutnd/ [20.10.2007].
} 
University of Malawi (1976-78), Boston College Law School (1993-94). Obok działalności naukowej zajmuje się Finnis także aktywnością, którą można by nazwać społeczną lub polityczną. Był więc w latach 1981-1984 członkiem Komitetu Wspólnego Katolickich Biskupów ds. Problemów Bioetycznych ciała powołanego do doradzania biskupom w kwestiach związanych z najnowszymi osiągnięciami technologicznymi ${ }^{2}$. Od tego samego roku bierze udział w projekcie o nazwie Linacre Centre for Health Care Ethics - jest to instytucja, powstała po to, by wyjaśniać katolikom (ale także osobom innych wyznań) stanowisko Kościoła w kontrowersyjnych kwestiach bioetycznych takich jak klonowanie, eutanazja czy aborcja. Finnis pełni funkcje wiceprezesa organizacji ${ }^{3}$. W latach 1990-1995 zasiadał w Papieskiej Komisji Iustitia et Pax, a od 2001 roku w utworzonej przez Jana Pawła II Papieskiej Akademii Życia. Ta ostatnia między innymi rozważa, jak w interdyscyplinarnej perspektywie rysują się podstawowe zagadnienia związane z promocją i ochroną życia, popierając szeroko rozumianą cywilizację życia ${ }^{4}$.

W Polsce koncepcja Finnisa jest znana głównie dzięki literaturze sekundarnej i, może przede wszystkim, podręcznikom filozofii i teorii prawa. Jeśli idzie o oryginalną twórczość filozofa, to wydana została tylko jej niewielka część. W 2001 roku nakładem warszawskiego Domu Wydawniczego ABC ukazał się przekład opus magnum filozofa Prawo naturalne i uprawnienia naturalne ${ }^{5}$. Cztery lata później pojawiło się krótkie wydawnictwo 0 racji publicznej (Fundacja Ius et Lex). Wciąż nieprzetłumaczona pozostaje reszta książek autora, wśród nich napisana wspólnie z J. M. Boylem Jr. i Germainem Grisezem Nuclear Deterrence, Morality, and Realism, a także Fundamentals of Ethics, Moral Absolutes: Tradition, Revision and Truth, oraz Aquinas: Moral, Political and Legal Theory. Prócz tego Finnis jest też autorem wielkiej ilości artykułów, publikowanych między innymi w „The American Journal of Jurisprudence” (wcześniej znanym jako „Natural Law Forum” - największe forum wymiany poglądów dotyczących prawa naturalnego), a także wielu rozdziałów w pracach zbiorowych, poruszających tematy leżące w kręgu zainteresowań Finnisa, takie jak homoseksualizm, aborcja czy małżeństwo.

Jak zostało wspomniane powyżej, John Finnis jest jednym ze współczesnych filozofów prawa zajmujących się doktryną prawa naturalnego. J. M.

${ }^{2}$ Zob. stronę internetową Komitetu Wspólnego Katolickich Biskupów d.s. Problemów Bioetycznych (Catholic Bishops' Joint Bioethics Committee), dostępne: http://www.catholicbioethics.org.uk/ [20.10.2007].

${ }^{3}$ Zob. stronę internetową The Linacre Centre, dostępne: http://www.linacre.org/ [20.10.2007].

${ }^{4}$ Zob. stronę internetową Papieskiej Akademii Pro Vita, dostępne: http://www.academiavita.org/ [20.10.2007].

${ }^{5}$ Patrz też: J. Finnis, Prawo naturalne i uprawnienia naturalne, w: Wspótczesna filozofia polityki. D. Pietrzyk-Reeves, B. Szlachta (red.), Kraków 2003, s. 237. 
Kelly wskazuje na kilka zrębów tworzących łącznie pełny obraz tej idei w ostatnich kilkudziesięciu latach. W pierwszej kolejności wymienia on europejskie teorie kwestionujące $\mathrm{z}$ tej pozycji teoretycznej pozytywizm prawniczy. Jako przedstawicieli tego nurtu wskazać należy Gustava Radbrucha, znanego jako autora formuły uznającej za niebyłe te ustawy, których stosowanie prowadzi do jawnej niesprawiedliwości ${ }^{6}$, a także francuskiego filozofa Micheala Villey. Obok nich wymienia Kelly anglosaskich filozofów prawa, zaczynając od (przewrotnie) teorii H. L. A. Harta, znanego przecież jako pozytywistę prawniczego, zawartej w książce Pojęcie prawa, a także autora Moralności prawa - Lona Fullera ${ }^{7}$. Wypada w tym miejscu poświęcić chwilę uwagi tym dwu postaciom. Wydaje się bowiem, iż dla zachowania uczciwości teoretycznej należy odnieść się do sporu pozytywistów z - rzecz ujmując bardzo szeroko - niepozytywistami. Słusznie konstatuje Lech Morawski, iż o ile przedstawiciele pozytywizmu prawniczego różnią się wewnętrznie między sobą (twardy - miękki pozytywizm), to jednak da się w ich poglądach wyróżnić pewne punkty wspólne, które pozwalają z całą stanowczością wskazać na ich przynależność do tego nurtu. Rzecz ma się jednak inaczej, jeśli chodzi o adwersarzy Harta czy J. Austina. Nie ulega wątpliwości, że spór z pozytywizmem prawniczym od dawna nie opiera się na jego opozycji do doktryn prawa naturalnego. Po drugiej stronie barykady ustawić można filozofów reprezentujących bardzo różne, nierzadko odległe od siebie, poglądy - takich jak R. Dworkin, J. Habermas czy J. Rawls. W tym też sensie, nie wdając się w szereg zagadnień związanych z systematyzacją stron samego sporu, jedyne, co wypada stwierdzić, to fakt, iż współcześnie nie można mówić li tylko o sporze pozytywizm - prawo naturalne, lecz raczej pozytywizm - niepozytywizm ${ }^{8}$, gdzie tę drugą stronę wyodrębnia się spośród tych filozofów, którzy budowali swój system negując wprost lub po prostu przedstawiając wizję alternatywną dla pozytywizmu prawniczego". Wracając natomiast do prawa naturalnego, to wydaje się, iż współcześnie jednym z najznamienitszych przedstawicieli tego prądu jest właśnie Finnis.

\footnotetext{
${ }^{6}$ L. Morawski, Wstęp do prawoznawstwa, Toruń 2006, s. 25.

J.M. Kelly, Historia zachodniej teorii prawa, Kraków 2006, s. 449.

${ }^{8}$ Może oczywiście istnieć pokusa, która pojawia się w przypadku innego sporu toczonego na gruncie współczesnej filozofii polityki - liberałów z komunitarystami - by postrzegać opisywaną powyżej dyskusję raczej jako „spór o pozytywizm”. Tak jednak, jak komunitaryzmowi nie da się przypisać tylko negatywnego stanowiska i określić go jako najwyżej antyliberalizm, to, przy całym uproszczeniu powyższych rozważań, nie da się też po prostu nazwać szeregu stanowisk niepozytywnymi. Jest to uproszczenie przyjęte $\mathrm{w}$ niniejszej pracy, by uniknąć dłuższych rozważań, a jednocześnie rozjaśnić wywód.

${ }^{9}$ L. Morawski, Główne problemy wspótczesnej filozofii prawa. Prawo $w$ toku przemian, Warszawa 2005, s. 328 i nn.
} 
Określa się Finnisa mianem przedstawiciela nowej szkoły czy też nowej teorii prawa naturalnego. Teoria zapoczątkowana została komentarzem do artykułu 2, kwestii 34 Summy teologicznej św. Tomasza, autorstwa Germaina Griseza z University of Notre Dame. Komentarz został opublikowany w „Natural Law Forum” (jak wspomniano, obecnie „American Journal of Jurisprudence”) w 1965 roku $^{10}$. Prócz dwóch wymienionych filozofów należy do przedstawicieli nowej teorii prawa naturalnego zaliczyć także Josepha Boyla (cała trójka wspólnie w 1987 roku napisała Nuclear Deterrence, Morality and Realism), a także Roberta P. Georga. Wokół szkoły narósł jednak cały szereg kontrowersji związanych z zakresem relacji między nową teorią a tradycyjnym tomizmem. Stawiano różnego rodzaju zarzuty odnoszące się do podstaw samej doktryny. By podać tylko przykład: Grisez, Finnis i George kwestionują istnienie hierarchii ludzkich celów - istnieje ostateczny cel, ale nie można ze względu na niego stwierdzić, iż jedno dobro podstawowe może być lepsze i z tego powodu mieć pierwszeństwo przed innym. Tymczasem McInerny ${ }^{11}$, odwołując się do Arystotelesa, konstatuje, że istnieje cel ostateczny, ze względu na który wyznaczyć można hierarchię ludzkich potrzeb $-u$ Arystotelesa jest nim kontemplacja. Idąc dalej, taki cel istnieje też u Tomasza i jest nim szczęście, którego osiągnięcie możliwe jest tylko w Bogu, ale o które zabiegać można też na ziemi ${ }^{12}$. Przykłady tego rodzaju można by tu mnożyć, jednak wydaje się, że współcześnie legitymizowanie jakiejś teorii i uznanie jej niepodważalnego znaczenia i wielkiej wagi następuje właśnie poprzez krytykę ${ }^{13}$.

By dopełnić celu niniejszej noty należy zasygnalizować kilka przynajmniej zagadnień z filozofii prawa australijskiego myśliciela. Wykazano powyżej, iż John Finnis tworzy, odwołując się do filozofii św. Tomasza, własną wersję teorii prawa naturalnego. Oto na jaki jej cel sam wskazuje: „nie musi być wcale (celem) dostarczanie opisowej nauce społecznej uzasadnionego szkieletu pojęciowego. (...) teoria taka może zostać skonstruowana głównie po to, aby ułatwić namysł praktyczny wszystkim tym, którzy muszą

\footnotetext{
${ }^{10}$ P. Łabieniec, Prawo rozumu. O teorii prawa naturalnego Johna Finnisa, Łódź 2004, s. 8.

${ }^{11}$ Sygnalizuje ten problem także, choć w odniesieniu tylko do Australijczyka, Alasdair MacIntyre recenzując książkę Finnisa Moral Absolutes: Tradition, Revision and Truth w „Ethics”, vol. 103, nr 4, 1993, s. 812.

${ }^{12}$ Ch. Wolfe, Natural Law Liberalism, New York 2006, s. 172.

${ }^{13}$ Wracając do przytaczanego tu sporu liberalizm-komunitaryzm; o ile w przypadku rawlsowskiego liberalizmu mamy do czynienia z krytyką ze strony komunitaryzmu właśnie, to $\mathrm{w}$ znaczeniu o jakim wspomniano powyżej sam Rawls dokonał legitymizacji komunitaryzmu podejmując rękawicę $\mathrm{z}$ jednej, ale przede wszystkim wydając zmodyfikowaną wersję swej teorii sprawiedliwości w Liberalizmie politycznym, z drugiej strony.
} 
podejmować jakieś działania czy to w charakterze sędziów, mężów stanu czy zwykłych obywateli" ${ }^{14}$. Wydaje się także, że Finnis również sam najtrafniej ocenia, czym jest prawo naturalne i wykazuje, że 1) istnieje zbiór rudymentarnych zasad praktycznych, które wskazują formy ludzkiego rozwoju jako dóbr, do których człowiek ma dążyć i realizować, 2) istnieje też zbiór podstawowych wymagań metodologicznych rozumności praktycznej. Jedno i drugie wspólnie pozwala zaś 3) wyróżnić zbiór ogólnych norm moralnych ${ }^{15}$. Przedstawia więc Finnis listę dóbr podstawowych, które wywodzone są przez przedfilozoficzne poznanie praktyczne. Nie da się żadnego z nich zredukować ani do dobra spoza listy, ani też między sobą. I tak wymienia Finnis wśród nich: życie, wiedzę, zabawę, przeżycia estetyczne, życie w społeczności (zwieńczone przyjaźnią), rozumność praktyczną i szeroko pojmowaną religię ${ }^{16}$. Do tego, by przekształcić je w ogólne normy moralne potrzebne są jednak dyrektywy metodologiczne rozumności praktycznej. One decydują o tym czy działanie jest rozumne w sensie praktycznym. Dyrektywy owe to: spójny plan życia, brak arbitralnych preferencji jednych wartości względem drugich, podobnie z ludźmi, zachowanie dystansu do podejmowanych przedsięwzięć, zaangażowanie i wytrwałość w ich podejmowaniu i kontynuowaniu, rozsądny wzgląd na skuteczność i konsekwencje działań, uwzględnianie $\mathrm{w}$ każdym $\mathrm{z}$ nich wszystkich podstawowych wartości, wspieranie dobra wspólnego społeczności, do których się należy, wreszcie, kierowanie się głosem sumienia ${ }^{17}$.

Jak wspomniano powyżej, Finnis zajmuje się nie tylko wysoce teoretycznymi rozważaniami, składającymi się na - jak ją nazwano - nową teorię prawa naturalnego. Wykazano, iż on sam widzi wysoce praktyczny wymiar swego rozumowania, stąd tak wielki fragment jego twórczości zajmują rozmyślania dotyczące współczesnych problemów natury moralnej. Jako przykład niech posłuży finnisowska odpowiedź na głośny artykuł Judith Thomson A Defence of Abortion, w której stawia cztery zasadnicze pytania, mające wpływać na odnalezienie słusznej odpowiedzi i właściwej moralnej oceny aborcji ${ }^{18}$ albo też jego stanowcze sądy dotyczące kwestii związków homoseksualnych ${ }^{19}$.

\footnotetext{
${ }^{14}$ J. Finnis, Prawo naturalne i uprawnienia naturalne, Warszawa 2001, s. 25.

${ }^{15}$ Tamże, s. 31.

${ }^{16}$ P. Łabieniec, Zarys teorii prawa naturalnego Johna Finnisa, „Ruch filozoficzny”, nr 3/4, t. LVI, 1999 , s. 332.

${ }^{17}$ K. Motyka, Wstęp, w: Prawo naturalne i uprawnienia naturalne, dz.cyt., s. XIV.

${ }^{18} \mathrm{~J}$. Finnis, The rights and wrongs of abortion: a reply to Judith Thomson, "Philosophy and public affairs", vol. 2, nr 2, 1973, s. 137 i nast.

${ }^{19} \mathrm{~J}$. Finnis, M. Nussbaum, Is homosexual conduct wrong? A philosophical exchange, "New republic", vol. 209, $\mathrm{nr}$ 20, 1995, s. 12 i nast.
} 
Pozycja australijskiego filozofa we współczesnej teorii prawa jest niekwestionowalna. Wydaje się jednak, być może, że z powodu wielkiej różnorodności stanowisk opozycyjnych w stosunku do pozytywizmu, cała nowa teoria prawa naturalnego nie doczekała się jeszcze wystarczającego całościowego omówienia w rodzimej literaturze sekundarnej. Pozostaje mieć nadzieję, że wydanie w języku polskim największej pracy Johna Finnisa będzie dobrym asumptem do znacznego wzrostu zainteresowania australijskim myślicielem i innymi przedstawicielami nowej teorii prawa naturalnego. 


\section{John Mitchell Finnis' place in contemporary theory of law}

John Mitchel Finnis was born in Australia in 1940. He was educated at the Australian University of Adelaide. As a Rhodes Scholar he earned his doctorate from the English Oxford University in 1965. Not only is he a Professor of Law at the Oxford University and the University of Notre Dame, but he also taught at the University of California at Berkeley, the African University of Malawi, Boston College Law School. $\mathrm{He}$ is a member of the Linacre Center for Health Care Ethics, the Pontifical Academy Pro Vita and he served an office at the Catholic Bishops' Joint Committee on Bioethical Issues, International Theological Commission and the Pontifical Council for Justice and Peace.

John Finnis is one of the best known representatives of the new natural law theory. Its originator was Germain Grisez - he published in "Natural Law Forum" in 1965 The First Principle of Practical Reason: A Commentary on the "Summa Theologiae", 1-2, q.94, a.2. Along with Joseph M. Boyle they wrote Nuclear Deterrence, Morality and Realism. Robert P. George is also known as one of its most prominent representatives. Together they try to construct a new version of the natural law theory although it is still strongly based on Aquinas' theory.

John Finnis focuses on complicated theoretical problems such as: intrinsically valuable basic human goods or practical reasonableness on the one hand, but on the other he is one of the most influential opponents of abortion, euthanasia or homosexuality among all philosophers.

Finnis' natural law theory is not well known in Poland. Only one book Natural Law and Natural Rights - is translated into Polish. This article was written to inspire Polish Readers to reach for John Finnis. 